\title{
Application of Gas Chromatography to Exuded Organic Matter Derived from Macroalgae
}

\author{
Shigeki Wada and Takeo Hama \\ Shimoda Marine Research Center, University of Tsukuba, \\ Life and Environmental Sciences, University of Tsukuba,
}

Japan

\section{Introduction}

Macroalgae are the most important primary producers in coastal environments, because their productivity per square community area is comparable to that of tropical rain forests (Mann, 1973; Yokohama et al., 1987). Although a half of the products constitute the organic matter of algal body (Hatcher et al., 1977), considerable part of them would be exuded and dissolved into ambient seawater (Khailov \& Burlakova, 1969; Sieburth, 1969; Hatcher et al., 1977; Abdullah \& Fredriksen, 2004; Wada et al., 2007). The organic materials released into ambient seawater induces some alteration of marine and atmospheric environments. For example, some volatile compounds released from macroalgae would escape into air, and play as ozone-depleting substances (Lovecock, 1975; Laturnus et al., 2010). Phenolic compounds are known as a kind of exudates, which acts as a form of defense to the algal body from herbivores (van Alstyne, 1988). A part of the phenolic compounds are likely to dissolve into seawater, and the light shielding role as a component of colored organic matter was suggested in coastal environments (Wada et al., 2007). In addition to these compounds, carbohydrates such as mucopolysaccharides are important component of released organic matter on the body surface, and a part of them is considered to be released into seawater (Wada et al., 2007). It is known that bacterial community acting on the macroalgae is variable depending on the carbohydrate composition of exudates (Bengtsson et al., 2011), and the bacterial community structure probably changes the carbon flux around algal bed. The characterization of organic compounds derived from macroalgae is necessary to elucidate the biogeochemical role of macroalgae, because the effect to biogeochemical processes is variable depending on each organic compound. Thus, quantitative and qualitative approaches have been carried out so far. Application of gas chromatography (GC) would be effective for some of these exuded compounds. In this review, we focused on the analytical methods using GC for analysis of compounds originated from macroalgae.

\section{Volatile halogenated organic matter}

\subsection{Macroalgal release of volatile halogenated organic matter}

Depletion of ozone in stratosphere has been focused as one of the most serious global environmental issues, and reaction of halogenated compounds with ozone has been 
recognized as the destruction mechanisms of ozone (Farman et al., 1985; Crutzen \& Arnold, 1986; Solomon, 1990; Anderson et al., 1991). Such volatile halogenated compounds are not only originated from anthropogenic sources, but also biogenic sources such as macroalgae. Due to such interests, volatile halogenated organic compounds (VHOC) have been intensely studied so far, and development of analytical technique of macroalgal VHOC has been recognized.

\subsection{Pre-treatment before injection}

When analysis of macroalgal VHOC in seawater samples are carried out, pre-treatment of the sample is important procedure for achievement of high recovery yield. There are several kinds of methods such as closed-loop stripping (CLSP), headspace, liquid-liquid extraction, purge-and-trap (P\&T) and solid-phase micro extraction (SPME) methods (Table 1). Within these methods, CLSP had been applied in earlier year (Gschwend et al., 1985; Newman and Gschwend, 1987), but there is a problem that the CLSP method is inappropriate for analyses of extremely volatile compounds (e.g., $\mathrm{CH}_{3} \mathrm{Cl}$ and $\mathrm{CH}_{3} \mathrm{Br}$ ) or relatively involatile compounds (e.g., $\mathrm{CBr}_{4}$ and $\mathrm{CHI}_{3}$ ) (Gschwend et al., 1985). In headspace method, seawater samples were brought into equilibrium with a gas (usually nitrogen) (Lovelock 1975; Manley \& Dastoor, 1987; Manley \& Dastoor, 1988; Manley et al., 1992). In the case that the concentrations of target compounds were low, cryo-concentration had been also applied (Manley \& Dastoor, 1987; Manley \& Dastoor, 1988; Manley et al., 1992). Liquid-liquid extraction is that solvent containing internal standard is added into seawater sample, and a part of the solvent phase was injected to GC. This method allows us to make analyses with simple instrumental set-up and the total analysis time is short (Abrahamsson \& Klick, 1990; Laturnus et al., 1996; Manley \& Barbero, 2001). P\&T method have been the most widelyapplied method in recent years. Sample seawater is purged with nitrogen or helium gases, and the target compounds in the gas phase were concentrated with cold trap (sometimes with adsorbent; Ekdahl \& Abrahamsson, 1997). After degassing, the trapped compounds were transferred into GC instrument by heating (Schall et al., 1994; Nightingale et al., 1995; Laturnus et al., 2004; Weinberger et al., 2007; Laturnus et al., 2010). Recently, SPME technique has been also applied for VHOC originated from macroalgae. SPME fibre is used for trapping of VHOC after purging with pure nitrogen. In case of determination of VHOC in seawater spiked by standards, quantitative quality was confirmed at the concentration level around $100 \mathrm{ng} \mathrm{l}^{-1}$ of VHOC (Bravo-Linares et al., 2010).

\subsection{GC Instruments}

Analyses of extracted VHOC compounds have been mainly carried out by gas chromatography with electron capture detector (GC-ECD) (e.g., Manley \& Dastoor, 1987; 1988; Schall et al., 1994; Laturnus et al., 1996; Manley \& Barbero, 2001; Laturnus et al., 2004) or gas chromatography/mass spectrometry (GCMS) (e.g., Gschwend et al., 1985; Newman \& Gschwend, 1987; Marshall et al., 1999; Bravo-Linares et al., 2010). Although GC-ECD has been commonly applied, it is necessary to confirm the retention time of each compound using authentic standards (Giese et al., 1999) or GCMS (Manley and Dastoor, 1987) to identify each component. On the other hand, application of GCMS has an advantage that it is reliable to characterize the compounds based on the mass spectrum. Capillary column is also an important part of GC for separation of each compound, and various kinds of 
columns (e.g., SE 54, BP-624, Rtx 502.2) have been applied. Most of them have mid-polarity, which have been commercially recommended for analysis of volatile organic compounds.

\begin{tabular}{|c|c|c|c|c|}
\hline Pre-treatment & Target compounds & Sample & Instruments & References \\
\hline Headspace & $\mathrm{CH}_{3} \mathrm{Cl}, \mathrm{CH}_{3} \mathrm{Br}, \mathrm{CH}_{3} \mathrm{I}$ & Seawater & GC-ECD & Lovelock (1975) \\
\hline $\begin{array}{l}\text { Closed loop } \\
\text { stripping }\end{array}$ & $\begin{array}{l}\mathrm{CHBr}_{3}, \mathrm{CHBr}_{2} \mathrm{Cl} \\
\mathrm{CH}_{2} \mathrm{Br}_{2}\end{array}$ & $\begin{array}{l}2 \text { Brown algae } \\
\text { and } 2 \text { Green } \\
\text { algae, }\end{array}$ & GCMS & $\begin{array}{l}\text { Gschwend } \\
\text { et al. (1985) }\end{array}$ \\
\hline $\begin{array}{l}\text { Closed loop } \\
\text { stripping }\end{array}$ & $\begin{array}{l}\left(\mathrm{CH}_{3}\right)_{2} \mathrm{CHBr}, \\
\mathrm{CH}_{3} \mathrm{CH}_{2} \mathrm{CH}_{2} \mathrm{Br}, \\
\mathrm{CH}_{3}\left(\mathrm{CH}_{2}\right)_{4} \mathrm{Br}, \mathrm{CH}_{3} \mathrm{I}, \\
\mathrm{C}_{2} \mathrm{H}_{5} \mathrm{I}, \mathrm{C}_{3} \mathrm{H}_{7} \mathrm{I}, \mathrm{C}_{4} \mathrm{H}_{9} \mathrm{I}, \\
\mathrm{C}_{5} \mathrm{H}_{11} \mathrm{I}, \mathrm{C}_{6} \mathrm{H}_{13} \mathrm{I}, \\
\mathrm{CH}_{2} \mathrm{Br}_{2}, \mathrm{CHBr}_{3}, \\
\mathrm{CH}_{2} \mathrm{I}_{2}, \mathrm{CHBr}_{2} \mathrm{I}, \\
\mathrm{CH}_{3} \mathrm{SCH}_{3}, \\
\mathrm{CH}_{3} \mathrm{SSCH}_{3} \\
\end{array}$ & 1 Brown algae & GCMS & $\begin{array}{l}\text { Newman \& } \\
\text { Gschwend } \\
(1987)\end{array}$ \\
\hline Headspace & $\mathrm{CH}_{3} \mathrm{Cl}, \mathrm{CHBr}, \mathrm{CH}_{3} \mathrm{I}$ & $\begin{array}{l}1 \text { Brown algae } \\
\text { and seawater }\end{array}$ & GC-ECD & $\begin{array}{l}\text { Manley \& } \\
\text { Dastoor (1987) }\end{array}$ \\
\hline Headspace & $\mathrm{CH}_{3} \mathrm{I}$ & 5 Brown algae & GC-ECD & $\begin{array}{l}\text { Manley \& } \\
\text { Dastoor (1988) }\end{array}$ \\
\hline Headspace & $\mathrm{CHBr}_{3}, \mathrm{CH}_{2} \mathrm{Br}_{2}, \mathrm{CH}_{3} \mathrm{I}$ & \begin{tabular}{|l|}
6 Brown algae, 3 \\
Red algae, 2 \\
Green algae and \\
seawater \\
\end{tabular} & GC-ECD & $\begin{array}{l}\text { Manley } \\
\text { et al. (1992) }\end{array}$ \\
\hline Headspace & $\mathrm{CHBr}_{3}, \mathrm{CH}_{2} \mathrm{Br}_{2}$ & 1 Brown algae & GC-ECD & $\begin{array}{l}\text { Goodwin } \\
\text { et al. (1997) }\end{array}$ \\
\hline Liquid-liquid & $\begin{array}{l}\mathrm{CHBr}_{3}, \mathrm{CH}_{2} \mathrm{Br}_{2}, \\
\mathrm{CHBr}_{2} \mathrm{Cl}, \mathrm{CH}_{2} \mathrm{I}_{2}, \\
\mathrm{CH}_{2} \mathrm{ClI}_{2} \mathrm{CCl}_{4} \\
\mathrm{CH}_{3} \mathrm{CCl}_{3}, \mathrm{CHClCl}_{2}\end{array}$ & Seawater & GC-ECD & Klick (1992) \\
\hline Liquid-liquid & $\begin{array}{l}\mathrm{CH}_{2} \mathrm{Br}_{2}, \mathrm{CHBrCl}_{2}, \\
\mathrm{CH}_{2} \mathrm{ClI}, \mathrm{CHBr}_{2} \mathrm{Cl}, \\
1,2-\mathrm{C}_{2} \mathrm{H}_{4} \mathrm{Br}_{2}, \mathrm{CH}_{2} \mathrm{I}_{2}, \\
\mathrm{CHBr}_{3}\end{array}$ & $\begin{array}{l}9 \text { Brown algae, } \\
15 \text { Red algae, } 2 \\
\text { Green algae and } \\
2 \text { Crysophyta }\end{array}$ & GC-ECD & $\begin{array}{l}\text { Laturnus } \\
\text { et al. (1996) }\end{array}$ \\
\hline Liquid-liquid & $\begin{array}{l}\mathrm{CH}_{2} \mathrm{Br}_{2}, \mathrm{CHBrCl}_{2}, \\
\mathrm{CH}_{2} \mathrm{ClI}, \mathrm{CHBr}_{2} \mathrm{Cl}, \\
1,2-\mathrm{C}_{2} \mathrm{H}_{4} \mathrm{Br}_{2}, \mathrm{CH}_{2} \mathrm{I}_{2}, \\
\mathrm{CHBr}_{3}\end{array}$ & $\begin{array}{l}11 \text { Brown algae, } \\
4 \text { Red algae and } \\
6 \text { Green algae }\end{array}$ & GC-ECD & Laturnus (1996) \\
\hline Liquid-liquid & $\begin{array}{l}\mathrm{CCl}_{4}, \mathrm{CHCl}=\mathrm{CCl}_{2}, \\
\mathrm{CCl}_{2}=\mathrm{CCl}_{2}, \mathrm{CH}_{2} \mathrm{Br}_{2}, \\
\mathrm{CHBr}_{3}, \mathrm{CH}_{2} \mathrm{ClI}, \\
\mathrm{C}_{4} \mathrm{H}_{9} \mathrm{I}, \mathrm{CH}_{2} \mathrm{I}_{2}\end{array}$ & Seawater & GC-ECD & $\begin{array}{l}\text { Abrahamsson \& } \\
\text { Ekdahl } \\
(1996)\end{array}$ \\
\hline Liquid-liquid & $\mathrm{CHBr}_{3}$ & 1 Green algae & GC-ECD & $\begin{array}{l}\text { Manley \& } \\
\text { Barbero } \\
(2001) \\
\end{array}$ \\
\hline
\end{tabular}




\begin{tabular}{|c|c|c|c|c|}
\hline Pre-treatment & Target compounds & Sample & Instruments & References \\
\hline Purge and trap & $\begin{array}{l}\mathrm{CH}_{3} \mathrm{I}, \mathrm{CHCl}_{3}, \\
\mathrm{CH}_{3} \mathrm{CCl}_{3}, \mathrm{CCl}_{4}, \\
\mathrm{CH}_{2} \mathrm{Br}_{2}, \mathrm{CHBrCl}_{2}, \\
\mathrm{CCl}_{2} \mathrm{CCl}_{2}, \mathrm{CHBr}_{2} \mathrm{Cl}\end{array}$ & $\begin{array}{l}5 \text { Brown algae, } 3 \\
\text { Red algae, } 3 \\
\text { Green algae and } \\
\text { seawater }\end{array}$ & GC-ECD & $\begin{array}{l}\text { Nightingale } \\
\text { et al. (1995) }\end{array}$ \\
\hline Purge and trap & $\begin{array}{l}\mathrm{CH}_{3} \mathrm{I}, \mathrm{CH}_{2} \mathrm{I}_{2}, \mathrm{CH}_{2} \mathrm{ClI}, \\
\mathrm{CH}_{3} \mathrm{CH}_{2} \mathrm{CH}_{2} \mathrm{I}, \\
\mathrm{CH}_{3} \mathrm{CHICH}_{3}, \\
\mathrm{CH}_{2} \mathrm{Br}_{2}, \mathrm{CHBr}_{3}, \\
\mathrm{CHBrCl}_{2}, \mathrm{CHBr}_{2} \mathrm{Cl}\end{array}$ & 3 Brown algae & GC-ECD & $\begin{array}{l}\text { Schall } \\
\text { et al. (1994) }\end{array}$ \\
\hline Purge and trap & $\begin{array}{l}\mathrm{C}_{2} \mathrm{H}_{5} \mathrm{Br}, 1,2-\mathrm{C}_{2} \mathrm{H}_{4} \mathrm{Br}_{2}, \\
\mathrm{C}_{2} \mathrm{H}_{5} \mathrm{I}, \mathrm{CH}_{2} \mathrm{ClI}, \\
\mathrm{CH}_{2} \mathrm{I}_{2}, \mathrm{CH}_{3} \mathrm{Br}, \\
\mathrm{CH}_{2} \mathrm{BrCl}_{2} \mathrm{CH}_{2} \mathrm{Br}_{2}, \\
\mathrm{CHBrCl}_{2}, \mathrm{CHBr}_{2} \mathrm{Cl}, \\
\mathrm{CHBr}_{3}\end{array}$ & $\begin{array}{l}4 \text { Brown algae, } 2 \\
\text { Red algae and } 4 \\
\text { Green algae }\end{array}$ & GC-ECD & Laturnus (1995) \\
\hline Purge and trap & $\mathrm{C}_{2} \mathrm{HCl}_{3}, \mathrm{C}_{2} \mathrm{Cl}_{4}$ & $\begin{array}{l}5 \text { Brown algae, } \\
17 \text { Red algae and } \\
6 \text { Green algae }\end{array}$ & GC-ECD & $\begin{array}{l}\text { Abrahamsson } \\
\text { et al. (1995) }\end{array}$ \\
\hline Purge and trap & $\begin{array}{l}\mathrm{CHBr}_{3}, \mathrm{CHCl}_{3}, \mathrm{CH}_{3^{-}} \\
\mathrm{CCl}_{3}, \mathrm{CH}_{2} \mathrm{Br}_{2}, \mathrm{CH}_{2} \mathrm{I}_{2}, \\
\mathrm{CH}_{3} \mathrm{I}, \mathrm{CHBr}_{2} \mathrm{Cl} \\
\mathrm{CHCl}_{2} \mathrm{Br}, \mathrm{CH}_{2} \mathrm{ClI}, \\
\mathrm{CCl}_{4}, \mathrm{Cl}_{2} \mathrm{C}=\mathrm{CCl}_{2}, \\
\mathrm{Cl}_{2} \mathrm{C}=\mathrm{CHCl}_{1} \mathrm{C}_{4} \mathrm{H}_{9} \mathrm{I}, \\
\mathrm{sec}_{-} \mathrm{C}_{4} \mathrm{H}_{9} \mathrm{I}, \mathrm{C}_{3} \mathrm{H}_{7} \mathrm{I}\end{array}$ & 1 Green algae & GC-ECD & $\begin{array}{l}\text { Mtolera } \\
\text { et al. (1996) }\end{array}$ \\
\hline Purge and trap & $\begin{array}{l}\mathrm{CH}_{3} \mathrm{I}, \mathrm{CH}_{2} \mathrm{I}_{2}, \mathrm{C}_{4} \mathrm{H}_{9} \mathrm{I}, \\
\mathrm{CH}_{2} \mathrm{ClI}, \mathrm{CHBr}_{3}, \\
\mathrm{CHBr}_{2} \mathrm{Cl}, \mathrm{CHBrCl}_{2}, \\
\mathrm{CHCl}_{3}, \mathrm{HCCl}=\mathrm{CCl}_{2}, \\
\mathrm{CH}_{2} \mathrm{Br}_{2}\end{array}$ & $\begin{array}{l}2 \text { Red algae and } \\
1 \text { Green algae }\end{array}$ & GC-ECD & $\begin{array}{l}\text { Pedersen } \\
\text { et al. (1996) }\end{array}$ \\
\hline Purge and trap & $\begin{array}{l}\mathrm{CH}_{2} \mathrm{I}_{2}, \mathrm{CH}_{2} \mathrm{BrCl} . \\
\mathrm{CHBrCl}_{2}, \\
\mathrm{C}_{2} \mathrm{H}_{5} \mathrm{Br}, 1,2- \\
\mathrm{C}_{2} \mathrm{H}_{4} \mathrm{Br}_{2}, \mathrm{C}_{2} \mathrm{H}_{5} \mathrm{I}, \\
\mathrm{CH}_{2} \mathrm{ClI} \\
\end{array}$ & $\begin{array}{l}3 \text { Red algae and } \\
1 \text { Green algae }\end{array}$ & GC-ECD & $\begin{array}{l}\text { Laturnus } \\
\text { et al. (1998) }\end{array}$ \\
\hline Purge and trap & 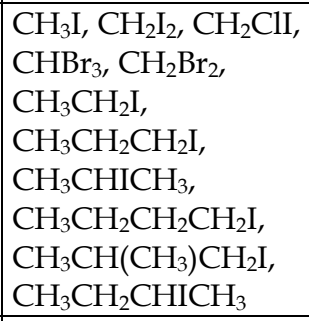 & $\begin{array}{l}2 \text { Brown algae, } \\
19 \text { Red algae and } \\
3 \text { Green algae }\end{array}$ & GC-ECD & $\begin{array}{l}\text { Giese } \\
\text { et al. (1999) }\end{array}$ \\
\hline Purge and trap & $\begin{array}{l}\mathrm{CHBr}_{3}, \mathrm{C}_{2} \mathrm{H}_{2} \mathrm{Br}_{2}, \\
\mathrm{CH}_{2} \mathrm{Br}_{2}\end{array}$ & 1 Red algae & GCMS & $\begin{array}{l}\text { Marshall } \\
\text { et al. (1999) }\end{array}$ \\
\hline
\end{tabular}




\begin{tabular}{|c|c|c|c|c|}
\hline Pre-treatment & Target compounds & Sample & Instruments & References \\
\hline Purge and trap & $\begin{array}{l}\mathrm{C}_{2} \mathrm{H}_{5} \mathrm{I}, 2-\mathrm{C}_{3} \mathrm{H}_{7} \mathrm{I}, 1- \\
\mathrm{C}_{3} \mathrm{H}_{7} \mathrm{I}, \mathrm{CH}_{2} \mathrm{ClI}, 2-\mathrm{n}- \\
\mathrm{C}_{4} \mathrm{H}_{9} \mathrm{I}, \mathrm{CH}_{2} \mathrm{I}_{2}, \mathrm{CHBr}_{3}\end{array}$ & 1 Red algae & GC-ECD & $\begin{array}{l}\text { Laturnus } \\
\text { et al. (2000) }\end{array}$ \\
\hline Purge and trap & $\mathrm{C}_{2} \mathrm{HCl}_{3}, \mathrm{C}_{2} \mathrm{Cl}_{4}$ & 1 Red algae & GCMS & $\begin{array}{l}\text { Marshall } \\
\text { et al. (2000) }\end{array}$ \\
\hline Purge and trap & $\begin{array}{l}\mathrm{CH}_{3} \mathrm{Br}, \mathrm{CH}_{3} \mathrm{Cl}, \\
\mathrm{CH}_{2} \mathrm{Cl}_{2}, \mathrm{CHCl}_{3}, \\
\mathrm{CH}_{3} \mathrm{I}, \mathrm{CH}_{2} \mathrm{ClI}, \\
\mathrm{CH}_{3} \mathrm{CH}_{2} \mathrm{I}\end{array}$ & $\begin{array}{l}2 \text { Brown algae, } 1 \\
\text { Red algae and } 3 \\
\text { Green algae }\end{array}$ & GC-ECD & $\begin{array}{l}\text { Baker } \\
\text { et al. (2001) }\end{array}$ \\
\hline Purge and trap & $\begin{array}{l}\mathrm{CH}_{3} \mathrm{Cl}, \mathrm{CH}_{3} \mathrm{Br} \\
\mathrm{CH}_{2} \mathrm{BrCl} \mathrm{CH}_{2} \mathrm{Br}_{2}, \\
\mathrm{CHBrCl}_{2}, \mathrm{CHBr}_{2} \mathrm{Cl}, \\
\mathrm{CHBr}_{3}, 1,2-\mathrm{C}_{2} \mathrm{H}_{4} \mathrm{Br}_{2} \\
\mathrm{CH}_{3} \mathrm{I}, \mathrm{CH}_{2} \mathrm{ClI}_{2} \mathrm{CH}_{2} \mathrm{I}_{2} \\
\mathrm{C}_{2} \mathrm{H}_{5} \mathrm{I}, 1-\mathrm{C}_{3} \mathrm{H}_{7} \mathrm{I}, 2- \\
\mathrm{C}_{3} \mathrm{H}_{7} \mathrm{I}, 1,3-\mathrm{C}_{3} \mathrm{H}_{6} \mathrm{ClI}, \\
\text { 1-n- }{ }_{4} \mathrm{H}_{9} \mathrm{I}, 20 \mathrm{n}- \\
\mathrm{C}_{4} \mathrm{H}_{9} \mathrm{I}, 1-\mathrm{iso}-\mathrm{C}_{4} \mathrm{H}_{9} \mathrm{I} \\
\end{array}$ & $\begin{array}{l}11 \text { Brown algae, } \\
11 \text { Red algae and } \\
8 \text { Green algae }\end{array}$ & $\begin{array}{l}\text { HRGC- } \\
\text { ECD/MIP } \\
\text { AED }\end{array}$ & Laturnus (2001) \\
\hline Purge and trap & $\begin{array}{l}\mathrm{CHCl}_{3}, \mathrm{C}_{2} \mathrm{HCl}_{3}, \\
\mathrm{C}_{2} \mathrm{Cl}_{4}, \mathrm{CHBr}_{3}, \\
\mathrm{CH}_{2} \mathrm{Br}_{2}, \mathrm{CHClBr}_{2}, \\
\mathrm{CH}_{2} \mathrm{BrCl}_{2} \mathrm{CHCl}_{2} \mathrm{Br}, \\
\mathrm{CH}_{2} \mathrm{I}_{2}, \mathrm{CH}_{3} \mathrm{I}, \mathrm{C}_{2} \mathrm{H}_{5} \mathrm{I}, \\
\mathrm{CH}_{2} \mathrm{ClI}, \mathrm{C}_{3} \mathrm{H}_{7} \mathrm{I}, \text { iso- } \\
\mathrm{C}_{3} \mathrm{H}_{7} \mathrm{I}, \mathrm{C}_{4} \mathrm{H}_{9} \mathrm{I} \text {, sec- } \\
\mathrm{C}_{4} \mathrm{H}_{9} \mathrm{I}\end{array}$ & $\begin{array}{l}1 \text { Brown algae, } 4 \\
\text { Green algae and } \\
1 \text { Diatom }\end{array}$ & GC-ECD & $\begin{array}{l}\text { Abrahamsson } \\
\text { et al. (2003) }\end{array}$ \\
\hline Purge and trap & $\begin{array}{l}\mathrm{C}_{2} \mathrm{Cl}_{4}, \mathrm{C}_{2} \mathrm{HCl}_{3}, \mathrm{CCl}_{4}, \\
\mathrm{CHCl}_{3}, \mathrm{CH}_{2} \mathrm{Cl}_{2}, \\
\mathrm{CH}_{3} \mathrm{CCl}_{3}, \mathrm{CH}_{3} \mathrm{I}, \\
\mathrm{CH}_{2} \mathrm{Br}_{2}, \mathrm{CHBr}_{3}, \\
\mathrm{CHBrCl}_{2}\end{array}$ & $\begin{array}{l}3 \text { Brown algae, } 1 \\
\text { Red algae and } 1 \\
\text { Green algae }\end{array}$ & GC-ECD & $\begin{array}{l}\text { Laturnus } \\
\text { et al. (2004) }\end{array}$ \\
\hline Purge and trap & $\begin{array}{l}\mathrm{CH}_{2} \mathrm{ICl}, \mathrm{CH}_{2} \mathrm{I}_{2}, \\
\mathrm{CH}_{2} \mathrm{IBr}, \mathrm{C}_{2} \mathrm{H}_{5} \mathrm{I}, 2- \\
\mathrm{C}_{3} \mathrm{H}_{7} \mathrm{I}, \mathrm{CH}_{3} \mathrm{I}, \mathrm{CH}_{2} \mathrm{Br}_{2}, \\
\mathrm{CHBr}_{3}\end{array}$ & seawater & GCMS & $\begin{array}{l}\text { Jones } \\
\text { et al. (2009) }\end{array}$ \\
\hline Purge and trap & $\begin{array}{l}\mathrm{CH}_{3} \mathrm{I}, \mathrm{CH}_{2} \mathrm{ClI}, \mathrm{CH}_{2} \mathrm{I}_{2}, \\
\mathrm{CH}_{2} \mathrm{Cl}_{2}, \mathrm{CHCl}_{3}, \\
\mathrm{CH}_{3} \mathrm{CCl}_{3}, \mathrm{CCl}_{4}, \\
\mathrm{C}_{2} \mathrm{HCl}_{3}, \mathrm{C}_{2} \mathrm{Cl}_{4}, \\
\mathrm{CH}_{2} \mathrm{Br}_{2}, \mathrm{CHBrCl}, \\
\mathrm{CHBr}_{2} \mathrm{Cl}, 1,2-\mathrm{EtBr}_{2}, \\
\mathrm{CHBr}_{3}\end{array}$ & 1 Brown algae & Not described & $\begin{array}{l}\text { Laturnus } \\
\text { et al. (2010) }\end{array}$ \\
\hline SPME & $\begin{array}{l}\mathrm{CH}_{3} \mathrm{Br}, \mathrm{CH}_{2} \mathrm{I}_{2}, \\
\mathrm{CCl}_{2}=\mathrm{CCl}_{2}, \mathrm{CHCl}_{2} \mathrm{Br}\end{array}$ & $\begin{array}{l}4 \text { Brown algae, } 2 \\
\text { Red algae and } 2 \\
\text { Green algae }\end{array}$ & GCMS & $\begin{array}{l}\text { Bravo-linares } \\
\text { et al. (2010) }\end{array}$ \\
\hline
\end{tabular}

Table 1. List of studies and methodologies used on VHOC originated from macroalgae 


\subsection{Estimation of the importance of macroalgal VHOC}

In order to evaluate macroalgal release of VHOC, an effective approach is seawater sampling in and out of algal bed in the field or incubation experiment in closed system. Analysis of seawater sample often showed higher concentration of VHOC around algal bed compared with offshore region, strongly suggesting the significant release of VHOC from macroalgae (Lovecock, 1975; Manley \& Dastoor, 1987; Klick, 1992; Manley et al., 1992; Nightingale et al., 1995). The incubation experiment can provide production rate of VHOC for each macroalgal species (Gschwend et al., 1985; Manley \& Dastoor, 1987). Assuming that the estimated production rate of VHOC is comparable with other macroalgae, some researchers estimated global VHOC production rates (Gschwend et al., 1985; Manley \& Dastoor, 1987). Although they multiplied the production rate per algal biomass which is experimentally defined by standing crop in global ocean, the most serious problem is that no detailed investigation on algal biomass in global ocean has been reported yet. Calculation of algal biomass in global ocean was estimated based on coastal length by De Vooys (1979) who also provided an estimation of primary production in global ocean as $0.03 \mathrm{PgC}^{-1}$. No estimate of biomass has been published by other researchers, but primary production was revised by Charpy-Roubaud \& Sournia (1990). They made estimation of primary production as $2.55 \mathrm{PgC}^{-1}$ based on algal community area, which is two orders of magnitude higher than the values of De Vooys (1979). Such discrepancy with the previous estimates implies that there is no reliable value of macroalgal parameters such as biomass and productivity in global ocean. In addition to the development of analytical technique, estimates of algal biomass in global ocean will be also required for understanding the macroalgal contribution to ozone-depletion.

\section{Phenolic compounds}

\subsection{Macroalgal phenolic compounds}

Macroalgae synthesize phenolic compounds, and a part of them is likely exuded (Paul et al., 2006). Considering that the phenolic compounds accumulated in the outer cortical layer of the thalli (Shibata et al., 2004; Paul et al., 2006), these materials would be actively released. Dissolution of phenolic compounds was also supported by in situ field experiment (Wada et al., 2007), in which absorption spectra of macroalgal excretion were relatively similar to those of the materials containing aromatic ring (lower exponential slope of the absorption spectra) (Blough \& Del Vecchio, 2002). The UV absorbing property of phenolic compounds (Łabudzińska \& Gorczyńska 1995) suggests the attenuation of UV radiation to seawater by phenolic compounds originated from macroalgae. Since biological activity in surface seawater is affected by UV penetration (Blough \& Del Vecchio, 2002), analysis of phenolic compounds shows the interaction between macroalgae and other marine organisms.

\subsection{Cupric oxide oxidation}

Analytical procedure for macroalgal phenolic compounds is cupric oxide $(\mathrm{CuO})$ oxidation method, in which polymeric compounds are degraded to small molecules that can be quantified by GC instrument. Although this technique has been mainly applied to lignin which also contains phenolic structure, some researchers had applied it to macroalgal materials (Goni \& Hedges, 1995). Generally, the samples were reacted with $\mathrm{CuO}$ at 150- 
$170^{\circ} \mathrm{C}$ for $3 \mathrm{~h}$ under alkaline conditions, and acidified after the reaction. The oxidized fraction was extracted with ethyl ether, and the solvent was evaporated. The products were dissolved in pyridine, and they are derivatised to trimethylsilyl derivatives for gas chromatographic analysis. Molecules containing aromatic ring were identified using GC or GCMS (Goni \& Hedges, 1995), but a possibility that some of them originated from protein, because 3 kinds of amino acids (phenylalanine, tryptophan and tyrosine) have aromatic group in their molecule. Since $m$-hydroxybenzoic acid and 3,5-dihydroxybenzoic acid has been suggested as non-amino acid derived from organic compounds containing phenolic structure such as tannin, these products are likely useful as an indicator of macroalgal materials when we use $\mathrm{CuO}$ oxidation method.

\subsection{Application of $\mathrm{CuO}$ oxidation method for macroalgal exudates}

There are just a few studies on analysis of phenolic compounds using $\mathrm{CuO}$ oxidation method (Goni \& Hedges, 1995), but they examined various species belonging to brown (Nereocystic luetkeana, Fucus fardneri, Costaria costata, Desmarestia viridis and Sargassum muticum), green (Ulva fenestrate and Codium fragile) and red algae (Opuntiella californica, Odonthalia floccose). In their study, there were 11 kinds of aromatic products after $\mathrm{CuO}$ oxidation, and m-hydroxybenzoic acid and 3,5-dihydroxybenzoic acid were determined as non-amino acid derived materials as described above. The contents of these two products in body weight of algae were the highest in the brown algae (1.5-2.3 and 4.3-14 times than red and green algae for m-hydroxybenzoic acid and 3.5-dihydroxybenzoic acid), suggesting that production of phenolic compounds by brown algae is larger than other macroalgal groups.

\section{Carbohydrates}

\subsection{Release of carbohydrates}

Macroalgal body is covered by sticky mucus due to excretion of materials containing mucopolysaccharides for protection of their body from external stress such as desiccation (Percival \& McDowell, 1981; Painter, 1983) and changes in ambient ion condition (Kloareg \& Quatrano, 1988). Since the monosaccharide composition of mucopolysaccharides is different among brown, red and green algae, monosaccharide analysis is effective to understand the original source of mucopolysaccharide. Here we described the chemical characteristics of carbohydrate species originated from these algae, and reviewed the methodological aspects of monosaccharide analysis.

\subsubsection{Brown algae}

The major mucopolysaccharide of brown algae is alginate, which is made up of two kinds of uronic acids (mannuronic acid and guluronic acid). The molar ratio of mannuronic acid to guluronic acid (M/G) ranges from 0.25 to 2.25 (Kloareg \& Quatrano, 1988). Another wellknown mucopolysaccharide is fucan, which comprises L-fucose and sulphate as major constituents. Actually, fucans are heterogeneous group of polysaccharide, and the fucose content ranges from 55 to $96 \%$ of total monosaccharides (Marais \& Joseleau, 2001; Bilan et al., 2004; 2006). Considering these monosaccharide composition, quantification of uronic acids and fucose would be available for characterization of mucopolysaccharides of brown algae. 


\subsubsection{Red algae}

Carrageenans are mainly extracted from Chondrus, Gigartina, Eucheuma and Hypnea, and they are highly sulphated galactans (De Ruiter \& Rudolph, 1997). These polysaccharides are categorized into several families based on the position of the sulphate groups. Agars are also a kind of galactan, but this is a low sulphated polymer, which is often extracted from Gelidium, Gracilaria, Ahnfeltia, Acanthopeltis and Pterocladia (Kloareg \& Quatrano, 1988). These polysaccharides are commonly found in red algae, and galactose is the major constituents.

\subsubsection{Green algae}

Mucopolysaccharides originated from green algae are highly branched sulphated heteropolysaccharides such as xylogalactoarabinans, glucuronoxylorhamnans and rhamnoxylogalacto-galacturonan (Kloareg \& Quatrano, 1988).

\subsection{Depolymerization and derivatization of carbohydrates}

\subsubsection{Depolymerization}

As mentioned above, monosaccharide composition reflects the original sources of the mucopolysaccharides released into extracellular region. For GC analysis of monosaccharide composition, it is necessary to depolymerize the polysaccharides and derivatize the monosaccharides in volatile forms. Well-known depolymerization and derivatization procedures are 1) hydrolysis-alditol-acetate or -trimethylsilyl and 2) methanolysistrimethylsilyl methods. In this section, we describe the features of the methods, and introduce the application to macroalgal carbohydrates.

\subsubsection{Acid hydrolysis}

Various acid solutions have been examined for hydrolytic depolymerization of polysaccharides in marine samples, and detail of the results was previously reviewed (Panagiotopoulos \& Sempere, 2005). Briefly, acid solutions which are mostly examined are $\mathrm{HCl}$ and $\mathrm{H}_{2} \mathrm{SO}_{4}$, and the recovery has been evaluated. Mopper (1973) compared these two acid solutions at same concentration $(2 \mathrm{~N})$, and suggested that $\mathrm{HCl}$ efficiently depolymerizes carbohydrate in ancient sediments but it led destruction of those in anoxic sediment (Mopper 1977). Acid strength is also important factor controlling the recovery yields. Two step of hydrolysis reaction, in which pre-treatment was carried out in $72 \% \mathrm{H}_{2} \mathrm{SO}_{4}$ solution at ambient temperature and diluted sample $(1-2 \mathrm{~N})$ was heated at $100^{\circ} \mathrm{C}$, are often used in order to achieve complete hydrolysis. These two steps reactions would be relatively strong, and sometimes induce loss of recovery of pentoses (Mopper, 1977), but the total yields of aldoses tend to be higher (Skoog \& Benner, 1997). Mild hydrolysis was performed in solutions of dilute $\mathrm{H}_{2} \mathrm{SO}_{4}, \mathrm{HCl}, \mathrm{CHCl}_{2} \mathrm{COOH}, \mathrm{H}_{3} \mathrm{PO}_{4},(\mathrm{COOH})_{2}$ and trifluoacetic acid. In some cases, their recoveries are comparable with those of strong hydrolysis reaction (Panagiotopoulos \& Sempere, 2005). However, they would be inappropriate for refractory species of carbohydrates such as cellulose (Skoog \& Benner, 1997).

\subsubsection{Derivatization and GC analysis}

Since carbohydrates are polyhydroxy compounds, it is essential to convert them into the volatile derivatives. Commonly used derivatization methods are trimethylsilylation and 
alditol-acetate derivatizations. Generally, hexamethyldisilazane and trimethylchlorosilan have been used as derivatizating agents and pyridine as solvent for trimethylsilylation. Analytical procedures of this technique are simple and rapid (Sweeley et al., 1963), and appropriate volatility is obtained. This technique would be also applicable to nonreducing sugars. However, monosaccharide with free carbonyl groups can be present as different tautomers, and each tautomeric form occurs as different peak. Consequently, such derivative method would provide complicated chromatogram in GC analysis. When complex sugar mixture is analyzed, reduction of the monosaccharides should be considered to avoid the overlapping of peaks (Ruiz-Matute et al., 2011). In alditol-acetate method, the carbonyl group of monosaccharide is reduced using reducing reagent (e.g., $\mathrm{KBH}_{4}$ ), and hydroxyl group of generated alditol is acetylated. This technique has several advantages, that alditol-acetate derivative produces single peak for each monosaccharide, and that the derivative is stable allowing clean-up for analysis (Knapp 1979). However, this method needs the large number of steps in the experimental procedures, and it is laborious and time consuming (Ruiz-Matute et al., 2011).

\subsubsection{Methanolysis}

Although hydrolysis is commonly used for analysis of neutral aldoses, the method is inappropriate for some kinds of carbohydrates such as uronic acid because of instability of uronic acid in acid hydrolysis reaction (Blake and Richards, 1968). Considering that uronic acid is also an important component of macroalgal mucopolysaccharides as mentioned above, alternative methodology should be examined. To overcome this problem, methanolysis reaction, which provides high recovery yields for uronic acid at $95-100 \%$ (Chambers and Clamp, 1971), is available.

Condition of methanolysis reaction commonly accepted is in $0.4-2 \mathrm{~N}$ methanolic $\mathrm{HCl}$ at $80^{\circ} \mathrm{C}$ for 5-24 h (Chambers \& Clamp, 1971; Doco et al., 2001; Mejanelle et al., 2002). Under this condition, the recoveries of both neutral aldoses and uronic acid are stable (Chambers and Clamp, 1971). Since methanolysis reaction is interfered by water, this reaction should be carried out after drying the samples completely. After depolymerization of polysaccharides by methanolysis reaction, trimethylsilyl derivatization has been usually applied (Dierckxsens et al., 1983; Bleton et al., 1996; Doco et al., 2001; Mejanelle et al., 2002). Since water in the sample interferes in the trimethylsilyl reaction as well as methanolysis reaction, drying of the sample is an essential procedure (Chamber \& Clamp, 1971)..

\subsubsection{GC analysis for methanolysis-trimethylsilyl derivatives}

In the methanolysis-trimethylsilyl method, several kinds of isomers are generated from one monosaccharide, and the chromatogram is often complicated due to the presence of a large number of peaks. Quantification of all of the isomers would be ideal, but detection of minor isomer peaks is sometimes difficult. In such a case, quantification is generally achieved by picking up major peaks, because the isomer composition would be constant regardless of initial chemical form of the monosaccharides if the methanolysis reaction was performed under same conditions (Mejanelle et al., 2002). Wada et al. (submitted) actually showed similar isomeric composition using seawater samples from natural environment and authentic standards.

The detail of GC or GCMS detection of methanolysis products has been already reviewed elsewhere (Mejanelle et al., 2004), and here we have simple explanation. When the analysis 
is carried out for less than 10 neutral and acidic monosaccharides, GC analysis will provide reliable identification of monosaccharide components. However, we should consider the presence of contaminant which is present in natural environment, because ambient seawater contains not only macroalgal exudates but organic constituents existing in seawater. In case that the contaminant peaks overlap with those of target monosaccharides, selective ion monitoring mode of GCMS instrument will be available (Wada et al., submitted). Using electron impact mode, some fragment ions are generated, and base peaks were $\mathrm{m} / \mathrm{z}$ 73, 204 and 217 in the most cases. Considering that the peaks at m/z 204 and 217 are often found for pyranosides and furanosides, respectively (Mejanelle et al., 2004), the composition of fragment ions will provide useful information about not only quantification, but also identification of the isomers generated by methanolysis reaction.

\subsection{Analysis of carbohydrates released from macroalgae}

Mucopolysaccharides which are known as extracellular carbohydrates have been analyzed using GC or GCMS after some purification treatments (Lee et al., 2004; Mandal et al., 2007; Karmakar et al., 2010; Rioux et al., 2010; Stephanie et al., 2010). On the other hand, direct analysis for carbohydrates released into ambient seawater is limited (Wada et al., 2007; 2008). In their studies, in situ field bag experiment was developed, and the carbohydrates released from a brown alga, Ecklonia cava, were obtained by SCUBA diving. By hydrolysis and alditol-acetate derivative method, it was shown that fucose is the major monosaccharide component (36-44\% of total carbohydrates), and that values had no significant seasonal variation. Since fucose is the major constituent of fucan derived from brown algae, constant dissolution of extracellular mucopolysaccharides into ambient environments from brown algae was suggested.

\section{Conclusion}

Macroalgae releases various organic compounds extracellularly and their role and dynamics in aquatic environments partly depend on the chemical composition. Since VHOC has been measured by numerous researchers, the VHOC analysis has been well improved in a few decades. On the other hand, there are possibilities of other unapplied option for phenolic compounds and carbohydrates analysis. For phenolic compounds, pyrolysis-GCMS is also considered as another potential tool, and Van Heemst et al. (1996) had tried to show the macroalgal contribution to marine organic matter pool. However, contamination of proteinaceous phenol under the process of pre-treatment was not as easy (Van Heemst et al., 1999). If this issue can be resolved in future, this instrument would also become a powerful tool for analysis of macroalgal phenolic compounds. Analysis of carbohydrates has been carried out for the extracts from algal body, but there is limited information on direct analysis of carbohydrates released to seawater as described above. Particularly, analysis using methanolysis method for seawater sample has been examined, yet. Thus, examination on the applicability of methanolysis method for seawater sample may be an important issue in the future.

\section{Acknowledgement}

This report is contribution no. 755 from the Shimoda Marine Research Center, University of Tsukuba. 


\section{References}

Abdullah, M. I. \& Fredriksen, S. (2004). Production, respiration and exudation of dissolved organic matter by the kelp Laminaria hyperborea along the west coast of Norway. Journal of Marine Biological Association of United Kingdom, Vol. 84, No. 5, pp. 887-894, ISSN 1469-7769

Abrahamsson, K. \& Klick, S. (1990). Determination of biogenic and anthropogenic volatile halocarbons in sea water by liquid-liquid extraction and capillary gas chromatography. Journal of Chromatography, Vol. 513, pp. 39-45, ISSN 0021-9673

Abrahamsson, K., Ekdahl, A., Collén, J. \& Pedersén M. (1995). Marine algae - a source of trichloroethylene and perchloroethylene. Limnology and Oceanography, Vol. 40, No. 7, (November 1995), pp. 1321-1326, ISSN 0024-3590

Abrahamsson, K. \& Ekdahl, A. (1996). Volatile halogenated compounds and chlorophenols in the Skagerrak. Journal of Sea Research, Vol. 35, No. 1-3, (February, 1996), pp. 7379, ISSN 1385-1101

Abrahamsson, K., Choo, K-S., Pedersén, M., Johansson, G. \& Snoeijs, P. (2003). Effects of temperature on the production of hydrogen peroxide and volatile halocarbons by brackish-water algae. Phytochemistry, Vol. 64, No. 3, (October 2003), pp. 725-734, ISSN 0031-9422

Anderson, J. G., Toohey, D. W. \& Brune, W. H. (1991). Free radicals within the Antarctic vortex: the role of CFCs in Antarctic ozone loss. Science, Vol. 251, No. 4989, (January 1991), pp. 39-46, ISSN 0036-8075

Baker, J. M., Sturges, W. T., Sugier, J. Sunnenberg, G., Lovett, A. A., Reeves, C. E., Nightingale, P. D. \& Penkett, S. A. (2001). Emissions of $\mathrm{CH}_{3} \mathrm{Br}$, organochlorines, and organoiodines from temperate macroalgae. Chemosphere - Global Change Science, Vol. 3, No. 1, (January 2001), pp. 93-106, ISSN 1465-9972

Bengtsson, M. M., Sjøtun, K., Storesund, J. E. \& Øvreås, L. (2011). Utilization of kelp-derived carbon sources by kelp surface-associated bacteria. Aquatic Microbial Ecology, Vol. 62, No. 2, (January 2011), pp. 191-199, ISSN 0948-3055

Bilan, M. I., Grachev, A. A., Ustuzhanina, N. E., Shashkov, A. S., Nifantiev, N. E. \& Usov, A. I. (2004). A highly regular fraction of a fucoidan from the brown seaweed Fucus distichus L. Carbohydrate Research, Vol. 339, No. 3, (February 2004), pp. 511-517, ISSN 0008-6215

Bilan, M. I., Grachev, A. A., Shashkov, A. S., Nifantiev, N. E. \& Usov, A. I. (2006). Structure of a fucoidan from the brown seaweed Fucus serratus L. Carbohydrate Research, Vol. 341, No. 2, (February 2006), pp. 238-245, ISSN 0008-6215

Blake, J. D. \& Richards, G. N. (1968). Problems of lactonisation in the analysis of uronic acids. Carbohydrate Research, Vol. 8, No. 3, (November 1968), pp. 275-281, ISSN 0008-6215

Bleton, J., Mejanelle, P., Sansoulet, J., Goursand, S. \& Tchapla, A. (1996). Characterization of neutral sugars and uronic acids after methanolysis and trimethylsilylation for recognition of plant gums. Journal of Chromatography A, Vol. 720, No. 1-2, (January 1996), pp. 27-49, ISSN 0021-9673

Blough, N. V. \& Del Vecchio, R. (2002). Chromophoric DOM in the coastal environment, In: Biogeochemistry of marine dissolved organic matter, Hansell, D. A. \& Carlson, C. A., (Eds.), 509-546, Academic Press, ISBN 0-12-323841-2, San Diego, USA 
Bravo-Linares, C. M., Mudge, S. M. \& Loyola-Sepulveda, R. H. (2010). Production of volatile organic compounds (VOCs) by temperate macroalgae. The use of solid phase microextraction (SPME) coupled to GC-MS as method of analysis. Journal of Chilean Chemical Society, Vol. 55, No. 2, (June 2010), pp. 227-232, ISSN 0717-9707

Chambers, R. E. \& Clamp, J. R. (1971). An assessment of methanolysis and other factors used in the analysis of carbohydrate-containing materials. Biochemistry Journal, Vol. 125, No. 4, (December 1971), pp. 1009-1018, ISSN 0264-6021

Charpy-Roubaud, C. \& Sournia, A. (1990). The comparative estimation of phytoplanktonic, microphytobenthic and macrophytobenthic primary production in the oceans. Marine Microbial Food Webs, Vol. 4, No. 1, pp. 31-57, ISSN 0297-8148

Crutzen, P. J. \& Arnold, F. (1986). Nitric acid cloud formation in the cold Antarctic stratosphere: a major cause for the springtime 'ozone hole'. Nature, Vol. 324, No. 6098, (December 1986), pp. 651-655, ISSN 0028-0836

De Ruiter, G. A. \& Rudolph, B. (1997). Carrageenan biotechnology, Trends in Food Science \& Technology, Vol. 8, No. 12, (December 1997), pp. 389-395, ISSN 0924-2244

De Vooys, C. G. N. (1979).Primary production in aquatic environments. In: The Global Carbon Cycle, Bolin, B., Degens, E. T., Kempe, S. \& Ketner, P., (Eds.), 259-292, Wiley, ISBN 978-0471997108, New York, USA

Dierckxsens, G. C., De Meyer, L. \& Tonino, G. J. (1983). Simultaneous determination of uronic acids, hexosamines, and galactose of glycosaminoglycans by gas-liquid chromatography. Analytical Biochemistry, Vol. 130, No. 1, (April 1983), pp. 120127, ISSN 0003-2697

Doco, T., O'Neill, M. A. \& Pellerin, P. (2001). Determination of the neutral and acidic glycosyl-residue compositions of plant polysaccharides by GC-EI-MS analysis of the trimethylsilyl methyl glycoside derivatives. Carbohydrate Polymers, Vol. 46, No. 3, (November 2001), pp. 249-259, ISSN 0144-8617

Ekdahl, A. \& Abrahamsson, K. (1997). A simple and sensitive method for the determination of volatile halogenated organic compounds in sea water in the amonl $1^{-1}$ to pmol $\mathrm{l}^{-1}$ range. Analytica Chimica Acta, Vol. 357, No. 3, (December 1997), pp. 197-209 ISSN 0003-2670

Farman, J. C., Gardiner, B. G. \& Shanklin, J. D. (1985). Large losses of total ozone in Antarctica reveal seasonal $\mathrm{ClO}_{x} / \mathrm{NO}_{x}$ interaction. Nature, Vol. 315, No. 6016, (May 1985), pp. 207-210, ISSN 0028-0836

Giese, B., Laturnus, F., Adams, F. C. \& Wiencke, C. (1999). Release of volatile iodinated C $1^{-}$ $\mathrm{C}_{4}$ hydrocarbons by marine macroalgae from various climate zones. Environmental Science and Technology, Vol. 33, No. 14, (June 1999), pp. 2432-2439, ISSN 0013-936X

Goñi, M. \& Hedges J. I. (1995). Sources and reactivities of marine-derived organic matter in coastal sediments as determined by alkaline $\mathrm{CuO}$ oxidation. Geochimica et Cosmochimica Acta, Vol. 59, No. 14, (July 1995), pp. 2965-2981, ISSN 0016-7037

Goodwin, K. D., North, W. J. \& Lidstrom, M. E. (1997). Production of bromoform and dibromomethane by Giant Kelp: Factors affecting release and comparison to anthropogenic bromine sources. Limnology and Oceanography, Vol. 42, No. 8, (December 1997), pp. 1725-1734, ISSN 0024-3590

Gschwend, P. M., MacFarlane, J. K. \& Newman, K. A. (1985). Volatile halogenated organic compounds released to seawater from temperate marine macroalgae. Science, Vol. 227, No. 4690, (March, 1985), pp. 1033-1035, ISSN 0036-8075 
Hatcher, B. G., Chapman, A. R. O. \& Mann, K. H. (1977). An annual carbon budget for the kelp Laminaria longicruris. Marine Biology, Vol. 44, No. 1, (March 1977), pp. 85-96, ISSN 0025-3162

Jones, C. E., Hornsby, K. E., Dunk, R. M., Leigh, R. J. \& Carpenter, L. J. (2009). Coastal measurements of short-lived reactive iodocarbons and bromocarbons at Roscoff, Brittany during the RHaMBLe campaign. Atmospheric Chemistry and Physics, Vol. 9, No. 4, pp. 8757-8769, ISSN 1680-7367

Karmakar, P., Pujol, C. A., Damonte, E. B., Ghosh, T. \& Ray, B. (2010) Polysaccharides from Padina tetrastromatica: structural features, chemical modification and antiviral activity. Carbohydrate Polymers, Vol. 80, No. 2, (December 2009), pp. 513-520, ISSN 0144-8617

Khailov, K. M. \& Burlakova, Z. P. (1969). Release of dissolved organic matter by marine seaweeds and distribution of their total organic production to inshore communities. Limnology and Oceanography, Vol. 14, No. 4, (July 1969), pp. 521527, ISSN 0024-3590

Klick, S. (1992). Seasonal variations of biogenic and anthropogenic halocarbons in seawater from a coastal site. Limnology and Oceanography, Vol. 37, No. 7, (November 1992), pp. 1579-1585, ISSN 0024-3590

Kloareg, B. \& Quatrano, R. S. (1988). Structure of the cell walls of marine algae and ecophysiological functions of the matrix polysaccharides. Oceanography and Marine Biology Annual Review, Vol. 26, pp. 259-315, ISSN 0078-3218

Knapp, D. R. (1979). Handbook of analytical derivatization reactions, Vol. 1, Wiley Interscience, ISBN 978-0-471-03469-8, New York, USA

Łabudzińska, A. \& Gorczyńska, K. (1995). The UV difference spectra as a characteristic feature of phenols and aromatic amines. Journal of Molecular Structure, Vol. 349, (April 1995), pp. 469-472, ISSN 0022-2860

Laturnus, F. (1995). Release of volatile halogenated organic compounds by unialgal cultures of polar macroalgae. Chemosphere, Vol. 31, pp. 3387-3395.

Laturnus, F. (1996). Volatile halocarbons released from Arctic macroalgae. Marine Chemistry, Vol. 55, pp. 359-366.

Laturnus, F., Wiencke, C. \& Klöser, H. (1996). Antarctic macroalgae-Sources of volatile halogenated organic compounds. Marine Environmental Research, Vol. 41, No. 2, pp. 169-181, ISSN 0141-1136

Laturnus, F., Wiencke, C. \& Adams, F. C. (1998). Influence of light conditions on the release of volatile halocarbons by Antarctic macroalgae. Marine Environmental Research, Vol. 45, No. 3, (April 1998), pp. 285-294, ISSN 0141-1136

Laturnus, F., Giese, B., Wiencke, C. \& Adams, F. C. (2000). Low-molecular-weight organoiodine and organobromine compounds released by polar macroalgae - The influence of abiotic factors. Fresenius Journal of Analytical Chemistry, Vol. 368, No. 2-3, (October 2000), pp. 297-302, ISSN 0937-0633

Laturnus, F. (2001). Marine macroalgae in polar regions as natural sources for volatile organohalogens. Environmental Science and Pollution Research International, Vol. 8, No. 2, pp. 103-108, ISSN 0944-1344

Laturnus, F., Svensson, T., Wiencke, C. \& Öberg, G. (2004). Ultraviolet radiation affects emission of ozone-depleting substances by marine macroalgae: results from a 
laboratory incubation study. Environmental Science and Technology, Vol. 38, No. 24, (December 2004), pp. 6605-6609, ISSN 0013-936X

Laturnus, F., Svensson, T. \& Wiencke, C. (2010). Release of reactive organic halogens by the brown macroalga Saccharina latissima after exposure to ultraviolet radiation. Polar Research, Vol. 29, No. 3, pp. 379-384, ISSN 1751-8369

Lee, J-B., Hayashi, K., Hashimoto, M., Nakano, T. \& Hayashi, T. (2004). Novel antiviral fucoidan from sporophyll of Undaria pinnatifida (Mekabu). Chemical Pharmaceutical Bulletin, Vol. 52, No. 9, (September 2004), pp. 1091-1094, ISSN 00092363

Lovelock, J. E. (1975). Natural halocarbons in the air and in the sea. Nature, Vol. 256, No. 5514, (July 1975), pp. 193-194, ISSN 0028-0836

Mandal, P., Mateu, C. G., Chattopadhyay, K., Pujol, C. A., Damonte, E. B. \& Ray, B. (2007). Structural features and antiviral activity of sulphated fucans from the brown seaweed Cystoseira indica. Antiviral Chemistry \& Chemotherapy, Vol. 18, No. 3, pp. 153-162, ISSN 0956-3202

Manley, S. L. \& Dastoor, M. N. (1987). Methyl halide $\left(\mathrm{CH}_{3} \mathrm{X}\right)$ production from the giant kelp, Macrocystis, and estimates of global $\mathrm{CH}_{3} \mathrm{X}$ production by kelp. Limnology and Oceanography, Vol. 32, No. 3, pp. 709-715, ISSN 0024-3590

Manley, S. L. \& Dastoor, M. N. (1988). Methyl iodide $\left(\mathrm{CH}_{3} \mathrm{I}\right)$ production by kelp and associated microbes. Marine Biology, Vol. 98, No. 4, pp. 477-482, ISSN 0025-3162

Manley, S. L., Goodwin, K. \& North, W. J. (1992). Laboratory production of bromoform, methylene bromide, and methyl iodide by macroalgae and distribution in nearshore southern California waters. Limnology and Oceanography, Vol. 37, No. 8, (December 1992), pp. 1652-1659, ISSN 0024-3590

Manley, S. L. \& Barbero, P. E. (2001). Physiological constraints on bromoform $\left(\mathrm{CHBr}_{3}\right)$ production by Ulva lactuca (Chlorophyta). Limnology and Oceanography, Vol. 46, No. 6, (September 2001), pp. 1392-1399, ISSN 0024-3590

Mann, K. H. (1973). Seaweeds: their productivity and strategy for growth. Science, Vol. 182, No. 4116, pp. 975-981, ISSN 0036-8075

Marais, M-F. \& Joseleau, J-P. (2001). A fucoidan fraction from Ascophyllum nodosum. Carbohydrate Research, Vol. 336, No. 2, (November 2001), pp. 155-159, ISSN 00086215

Marshall, R. A., Harper, D. B., McRoberts, W. C. \& Dring, M. J. (1999). Volatile bromocarbons produced by Falkenbergia stages of Asparagopsis spp. (Rhodophyta). Limnology and Oceanography, Vol. 44, No. 5, (July 1999), pp. 1348-1352, ISSN 0024-3590

Marshall, R. A., Hamilton, J. T. G., Dring, M. J. \& Harper, D. B. (2000). The red alga Asparagopsis taxiformis/Falkenbergia hillebrandii - a possible source of trichloroethylene and perchloroethylene? Limnology and Oceanography, Vol. 45, No. 2 (March 2000) pp. 516-519, ISSN 0024-3590

Mejanelle, P., Bleton, J., Tchapla, A. \& Goursaud, S. (2002). Gas chromatography-mass spectrometric analysis of monosaccharides after methanolysis and trimethylsilylation. Potential for characterization of substances of vegetal origin: application to the study of museum objects. Journal of Chromatography Library, Vol. 66, pp. 845-902, ISSN 0301-4770 
Mopper, K. (1973). Aspects of the biogeochemistry of carbohydrates in aquatic environments. Thesis, M. I. T. - Woods Hole Oceanographic Institution Joint Program in Oceanography.

Mopper, K. (1977). Sugars and uronic acids in sediment and water from the Black Sea and North Sea with emphasis on analytical techniques. Marine Chemistry, Vol. 5, No. 46, (November 1977), pp. 585-603, ISSN 0304-4203

Mtolera, M. S. P., Collén, J., Pedersén, M., Ekdahl, A., Abrahamsson, K. \& Semesi, A. K. (1996). Stress-induced production of volatile halogenated organic compounds in Eucheuma denticulatum (Rhodophyta) caused by elevated $\mathrm{pH}$ and high light intensities. European Journal of Phycology, Vol. 31, No. 1, pp. 89-95, ISSN 09670262

Newman, K. A. \& Gschwend, P. M. (1987). A method for quantitative determination of volatile organic compounds in marine macroalgae. Limnology and Oceanography, Vol. 32, No. 3, (May 1987), pp. 702-708, ISSN 0024-3590

Nightingale, P. D., Malin, G. \& Liss, P. S. (1995). Production of chloroform and other lowmolecular-weight halocarbons by some species of macroalgae. Limnology and Oceanography, Vol. 40, No. 4, (June 1995), pp. 680-689, ISSN 0024-3590

Painter, T. J. (1983). Algal polysaccharides. In: The polysaccharides, Aspinall, G. O., (Ed.), Vol. 2, 195-285, Academic Press, ISBN 0-12-065602-7, New York, USA

Panagiotopoulos, C. \& Sempéré, R. (2005). Analytical methods for the determination of sugars in marine samples: a historical perspective and future directions. Limnology and Oceanography: Methods, Vol. 3, (January 2005), pp. 419-454, ISSN 1541-5856

Paul, V. J., Puglisi, M. P. \& Ritson-Williams, R. (2006). Marine chemical ecology, Natural Product Reports, Vol. 23, (February 2006), pp. 153-180, ISSN 0265-0568

Pedersén, M., Collén, J., Abrahamsson, K. \& Ekdahl, A. (1996). Production of halocarbons from seaweeds: an oxidative stress reaction? Scientia Marina, Vol. 60, pp. 257-263, ISSN 0214-8358

Percival, E. \& McDowell, R. H. (1981). Algal cell walls-composition and biosynthesis. In: Encyclopedia of plant physiology, Tanner, W. \& Loewus, F. A., (Eds.), Vol. 13, 277 316, Springer, ISBN 0-387-11007-0, New York, USA

Rioux, L-E., Turgeon, S. L. \& Beaulieu, M. (2010). Structural characterization of laminaran and galactofucan extracted from the brown seaweed Saccharina longicruris. Phytochemistry, Vol. 71, No. 13, (September 2010), pp. 1586-1595, ISSN 0031-9422

Ruiz-Matute, A. I., Hernández-Hernández, O., Rodríguez-Sánchez, S., Sanz, M. L. \& Martínez-Castro, I. (2011). Derivatization of carbohydrates for GC and GC-MS analyses. Journal of Chromatography B, Vol. 879, No. 17-18, (May 2011), pp. 12261240, ISSN 1570-0232

Schall, C., Laturnus, F. \& Heumann, K. G. (1994). Biogenic volatile organoiodine and organobromine compounds released from polar macroalgae. Chemosphere, Vol. 28, No. 7, (April 1994), pp. 1315-1324, ISSN 0045-6535

Shibata, T., Hama, Y., Miyasaki, T., Ito, M. \& Nakamura, T. (2006). Extracellular secretion of phenolic substances from living brown algae. Journal of Applied Phycology, Vol. 18, No. 6, (December 2006), pp. 787-794, ISSN 0921-8971

Sieburth, J. M. (1969). Studies on algal substances in the sea. III. The production of extracellular organic matter by littoral marine algae. Journal of Experimental Marine Biology and Ecology, Vol. 3, No. 3, pp. 290-309, ISSN 0022-0981 
Skoog, A. \& Benner, R. (1997). Aldoses in various size fractions of marine organic matter: implications for carbon cycling. Limnology and Oceanography, Vol. 42, No. 8, (December 1997), pp. 1803-1813, ISSN 0024-3590

Solomon, S. (1990). Progress towards a quantitative understanding of Antarctic ozone depletion. Nature, Vol. 347, No. 6291, (September 1900), pp. 347-354, ISSN 00280836

Stephanie, B., Eric, D., Sophie, F. M., Christian, B. \& Yu, G. (2010) Carrageenan from Solieria chordalis (Gigartinales): structural analysis and immunological activities of the low molecular weight fractions. Carbohydrate Polymers, Vol. 81, No. 2, (June 2010), pp. 448-460, ISSN 0144-8617

Sweeley, C. C., Bentley, R., Makita, M \& Wells, W. W. (1963). Gas-liquid chromatography of trimethylsilyl derivatives of sugars and related substances. Journal of the American Chemical Society, Vol. 85, No. 16, pp. 2497-2507, ISSN 0002-7863

Van Alstyne, K. L. (1988). Herbivore grazing increases polyphenolic defenses in the intertidal brown alga Fucus distichus. Ecology, Vol. 69, No. 3, 655-663, ISSN 00129658

Van Heemst, J. D. H., Peulvé, S. \& De Leeuw, J. W. (1996). Novel algal polyphenolic biomacromolecules as significant contributors to resistant fractions of marine dissolved and particulate organic matter. Organic Geochemistry, Vol. 24, No. 6-7, (June 1996), pp. 629-640, ISSN 0146-6380

Van Heemst, J. D. H., Van Bergen, P. F., Stankiewicz, B. A. \& De Leeuw, J. W. (1999). Multiple sources of alkylphenols produced upon pyrolysis of DOM, POM and recent sediments. Journal of Analytical and Applied Pyrolysis, Vol. 52, No. 2, (November 1999), pp. 239-256, ISSN 0165-2370

Wada, S., Aoki, M. N., Tsuchiya, Y., Sato, T., Shinagawa, H. \& Hama, T. (2007). Quantitative and qualitative analyses of dissolved organic matter released from Ecklonia cava Kjellman, in Oura bay, Shimoda, Izu Peninsula, Japan. Journal of Experimental Marine Biology and Ecology, Vol. 349, No. 2, (October 2007), pp. 344-358, ISSN 0022-0981

Wada, S., Aoki, M. N., Mikami, A., Komatsu, T., Tsuchiya, Y., Sato, T., Shinagawa, H. \& Hama T. (2008). Bioavailability of macroalgal dissolved organic matter in seawater. Marine Ecology-Progress Series, Vol. 370, (October 2008), pp. 33-44, ISSN 0171-8630

Weinberger, F., Coquempot, B., Forner, S., Morin, P., Kloareg, B. \& Potin, P. (2007). Different regulation of haloperoxidation during agar oligosaccharide-activated defense mechanisms in two related red algae, Gracilaria sp. and Gracilaria chilensis. Journal of Experimental Botany, Vol. 58, No. 15-16, pp. 4365-4372, ISSN 0022-0957

Yokohama, Y., Tanaka, J. \& Chihara, M. (1987). Productivity of the Ecklonia cava community in a bay of Izu Peninsula on the Pacific coast of Japan. The Botanical Magazine, Tokyo, Vol. 100, No. 2pp. 129-141, ISSN 0918-9440 




\author{
Advanced Gas Chromatography - Progress in Agricultural, \\ Biomedical and Industrial Applications \\ Edited by Dr. Mustafa Ali Mohd
}

ISBN 978-953-51-0298-4

Hard cover, 460 pages

Publisher InTech

Published online 21, March, 2012

Published in print edition March, 2012

Progress in agricultural, biomedical and industrial applications' is a compilation of recent advances and developments in gas chromatography and its applications. The chapters cover various aspects of applications ranging from basic biological, biomedical applications to industrial applications. Book chapters analyze new developments in chromatographic columns, microextraction techniques, derivatisation techniques and pyrolysis techniques. The book also includes several aspects of basic chromatography techniques and is suitable for both young and advanced chromatographers. It includes some new developments in chromatography such as multidimensional chromatography, inverse chromatography and some discussions on two-dimensional chromatography. The topics covered include analysis of volatiles, toxicants, indoor air, petroleum hydrocarbons, organometallic compounds and natural products. The chapters were written by experts from various fields and clearly assisted by simple diagrams and tables. This book is highly recommended for chemists as well as non-chemists working in gas chromatography.

\title{
How to reference
}

In order to correctly reference this scholarly work, feel free to copy and paste the following:

Shigeki Wada and Takeo Hama (2012). Application of Gas Chromatography to Exuded Organic Matter Derived from Macroalgae, Advanced Gas Chromatography - Progress in Agricultural, Biomedical and Industrial Applications, Dr. Mustafa Ali Mohd (Ed.), ISBN: 978-953-51-0298-4, InTech, Available from: http://www.intechopen.com/books/advanced-gas-chromatography-progress-in-agricultural-biomedical-andindustrial-applications/application-of-gas-chromatography-to-exuded-organic-matter-derived-from-macroalgae

\section{INTECH}

open science | open minds

\section{InTech Europe}

University Campus STeP Ri

Slavka Krautzeka 83/A

51000 Rijeka, Croatia

Phone: +385 (51) 770447

Fax: +385 (51) 686166

www.intechopen.com

\section{InTech China}

Unit 405, Office Block, Hotel Equatorial Shanghai

No.65, Yan An Road (West), Shanghai, 200040, China 中国上海市延安西路65号上海国际贵都大饭店办公楼405单元

Phone: +86-21-62489820

Fax: +86-21-62489821 
(C) 2012 The Author(s). Licensee IntechOpen. This is an open access article distributed under the terms of the Creative Commons Attribution 3.0 License, which permits unrestricted use, distribution, and reproduction in any medium, provided the original work is properly cited. 